\section{Antiviral effect of interferon in vivo may be mediated by the host}

INTERFERON has antiviral effects both in vivo and in vitro. Viral replication is inhibited in interferon-treated cells in vitro because the reproductive cycle of the virus is inhibited at the transcriptional or translational level, depending on the viruscell system studied ${ }^{1}$. This direct inhibition of viral replication has been assumed to also be the mechanism by which interferon exerts its antiviral effect in vivo. We report here results that indicate protection by interferon against viral infection in vivo without inhibition of the viral replication of the same virus in vitro.

To test the antiviral effect of human leukocyte interferon (HLI) in vivo, six rhesus monkeys were infected intradermally with different doses of vaccinia virus (strain of the Rijks Instituut voor de Volksgezondheid, RIV) ${ }^{2}$ of which three were treated daily with HLI administered intramuscularly. The HLI was prepared as described previously ${ }^{3}$. The preparation used in these experiments had a specific activity of $2.1 \times 10^{6}$ units per $\mathrm{mg}$ protein. In control monkeys the lesions reached their maximum at day 7. Daily intramuscular injections of $5 \times 10^{5}$ units HLI per $\mathrm{kg}$ body weight during $8 \mathrm{~d}$ completely inhibited the development of the typical vaccinia-induced skin lesions (Fig. 1). No skin lesions were detected during the observation period of 4 weeks following infection. However, we were unable to correlate this distinct in vivo effect of HLI with a corresponding inhibition of the cytopathogenic effect (CPE) of the same virus on dipłid rhesus monkey skin fibroblasts or on Rous sarcoma virus transformed human fibroblasts (RSb cells). Up to $10^{4}$ units of HLI failed to protect the cells against the CPE of vaccinia virus (RIV strain), although the CPE of vesicular stomatitis virus (VSV) was effectively inhibited (Table 1). Surprisingly, vaccinia virus was resistant to interferon in our in vitro system, but the same results were obtained in vitro with the vaccinia virus strain WR and with smaller challenge doses $\left(10^{-3} \mathrm{TCID}_{50}\right)^{4}$. Also no anti-vaccinia activity could be detected in the sera of the monkeys $4 \mathrm{~h}$ after the first injection with HLI. At this time, the sera showed the maximum titre of antiviral activity when tested against VSV. Similar experiments performed with human diploid skin fibro-

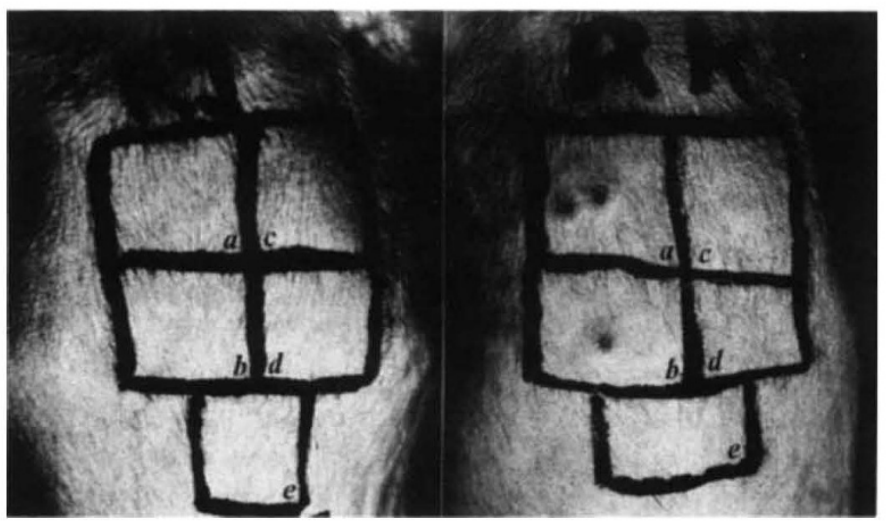

Fig. 1 In vivo effect of human leukocyte interferon (HLI) in rhesus monkeys infected intradermally with vaccinia virus. Monkeys were treated with HLI from day -1 to day 7 at $5 \times 10^{5}$ units $\mathrm{kg}^{-1}$ i.m. They were vaccinated intradermally at day 0 with the following preparations: $10^{7} \operatorname{TCID}_{50} \mathrm{ml}^{-1}$ vaccinia virus $(a)$; $10^{6} \mathrm{TCID}_{50} \mathrm{ml}^{-1}$ vaccinia virus $(b) ; 10^{5} \mathrm{TCID}_{50} \mathrm{ml}^{-1}$ vaccinia virus $(c) ; 10^{7}$ TCID $_{50} \mathrm{ml}^{-1}$ vaccinia virus, subjected to $\mathrm{UV}$ - and heat-inactivation $(d) ; \mathrm{NaCl}(e)$. For each dilution, $0.05 \mathrm{ml}$ were injected at three sites. The vaccination sites $12 \mathrm{~d}$ after infection are shown in a rhesus monkey treated with HLI (left) and in a control monkey (right). Three monkeys were treated with interferon and three served as controls.
Table 1 In vitro inhibition of the cytopathogenic effect (CPE) of vaccinia virus by human leukocyte interferon (HLI) and serum from rhesus monkeys treated with HLI

\begin{tabular}{|c|c|c|c|c|}
\hline \multirow[b]{2}{*}{ Preparation } & \multicolumn{2}{|c|}{ RSb cells } & \multicolumn{2}{|c|}{$\begin{array}{l}\text { Skin fibroblasts from } \\
\text { rhesus monkeys }\end{array}$} \\
\hline & VSV & $\begin{array}{l}\text { Vaccinia } \\
\text { virus }\end{array}$ & VSV & $\begin{array}{l}\text { Vaccinia } \\
\text { virus }\end{array}$ \\
\hline $\begin{array}{l}\text { HLI, } 10^{4} \text { units } \mathrm{ml}^{-1} \\
\text { Pre-serum* } \\
\text { Post-serum* }\end{array}$ & $\begin{array}{l}10,000 \\
<10 \dagger \\
350 \dagger\end{array}$ & $\begin{array}{l}<1 \\
<10 \\
<10\end{array}$ & $\begin{array}{l}10,000 \\
\text { ND } \\
\text { ND }\end{array}$ & $\begin{array}{l}<1 \\
\text { ND } \\
\text { ND }\end{array}$ \\
\hline
\end{tabular}

Rous sarcoma virus transformed human fibroblasts (RSb) or monkey skin fibroblasts were plated in microtitre plates, grown to confluency $\left(4 \times 10^{4}\right.$ cells per well) and treated with serial dilutions of HLI containing $10^{4}$ units per $\mathrm{ml}$ of rhesus monkey sera (before and after injection of $5 \times 10^{5}$ units $\mathrm{HLI} \mathrm{kg} \mathrm{kg}^{-1}$ ). After overnight incubation, the supernatant was removed and cells were infected with vesicular stomatitis virus (VSV) or vaccinia virus (multiplicity of infection 0.25 TCID $_{50}$ per cell). The incubation was terminated when untreated infected control cells showed more than $90 \%$ CPE. The cells were stained with crystal violet. Both viruses were always tested simultaneously in the same microtitre plate and an interferon standard preparation was inciuded. The activity of interferon is expressed as the reciprocal of the highest dilution giving $50 \%$ protection. The titres are given as reference units (tested against standard preparation 69/19).

* Before and after $4 \mathrm{~h}$ after injection of rhesus monkeys with $5 \times 10^{5}$ units of HLI per $\mathrm{kg}$.

† Mean titre of three monkeys. ND, not determined.

blasts and rhesus monkey kidney cells showed identical results. There was also no inhibition of the production of infectious vaccinia virus (unpublished results).

These findings indicate that interferon can be effective in vivo against a virus which is insensitive to its antiviral action in various cell types. Likewise, it has been shown by others ${ }^{5}$ that interferon can inhibit in vivo the growth of tumour cells which are resistant to its growth inhibitory action in vitro. Interferon may activate several defence systems of the host, for example, the cytotoxicity of the natural killer cells and the macrophages $^{6.7}$. Perhaps such 'aggressive' cells can selectively destroy virus-infected cells in vivo.

We thank Dr H. Balner and Professor N. Masurel for their help and R. Sahadat for technical assistance.

\section{H. SCHELLEKENS}

\author{
Department of Virology, \\ Erasmus University, \\ PO Box 1738, Rotterdam
}

W. WEIMAR

Department of Internal Medicine,

Erasmus University,

Rotterdam, The Netherlands

\section{K. CANTEll}

State Serum Institute,

Helsinki,

Mannerheimintie 166, Finland

\section{STITZ}

Primate Center TNO,

Virology Section,

151, Lange Kleiweg,

$2280 \mathrm{HV}, \mathrm{Rijswijk}$, The Netherlands

Received 25 November 1978; accepted 16 February 1979.

1. Friedman, R. Bact. Rev. 3, 543-567 (1977).

. Hekker, A. C., Bos, J. M. \& Smith, L. J. biol. Stands 1, 21-32 (1973)

3. Cantell, K. \& Hirvonen, S. J. gen. Virol. 39, 541-543 (1978).

4. Stitz, L. \& Schellekens, H. (submitted).

. Gresser, I., Maury, C. \& Brouty-Boyê,, D. Nature 239, 167-168 (1972).

6. Gresser, I. \& Tovey, M. G. Biochim. biophys. Acta 516, 231-247 (1978)

7. Gidlund, M., Örn, A., Wigzell, H., Senik, A. \& Gresser, I. Nature 273, 759-761 (1978). 